\title{
Implementasi Model Pembelajaran Inkuiri Terbimbing untuk Meningkatkan Motivasi Belajar dan Kemampuan Berpikir Kritis
}

\section{Ni Wayan Wartini ${ }^{1^{*}}$}

${ }^{1}$ SMK Negeri 1 Mas Ubud Gianyar

\section{A R T I C L E I N F O}

Article history:

Received 20 October 2020

Received in revised form

30 November 2020

Accepted 10 January 2021

Available online 01

February 2021

\section{Kata Kunci:}

Model Pembelajaran

Inkuiri Terbimbing

Motivasi Belajar,

Kemampuan Berpikir

Kritis

Keywords:

Guided Inquiry Learning

Model, Learning

Motivation, Skill Critice

Thinking.

\begin{abstract}
A B S T R A K
Penelitian ini bertujuan untuk mengkaji implementasi model pembelajaran Inkuiri tebimbing untuk meningkatkan maotivasi belajar dan kemampuan berpikir kritis. Jenis penelitian ini adalah Penelitian Tindakan Kelas (PTK) yang dilakukan dalam dua siklus. Subjek penelitian ini adalah siswa kelas XI. yang berjumlah 30 orang terdiri dari 5 siswa perempuan dan 25 orang siswa laki-laki. Data dikumpulkan dengan angket dan tes kemampuan berpikir kritis tipe esay. Data yang dikumpulkan kemudian dianalisis secara deskriptif. Hasil penelitian menunjukkan 1) penerapan model pembelajaran inkuri terbimbing mampu meningkatkan motivasi belajar siswa. Rata-rata skor motivasi belajar siswa berada pada kategori tinggi dengan rata-rata skor 103,73 pada siklus I dan 109,27 pada siklus II dengan kategori tinggi. 2) Penerapan model pembelajaran inkuiri terbimbing mampu meningkatkan kemampuan berpikir kritis siswa. Rata-rata nilai kemampuan berpikir kritis siswa berada pada kategori baik dengan ketuntasan klasikal sebesar $87,1 \%$ pada siklus I dan ketuntasan klasikal sebesar $90,6 \%$ pada siklus II dengan kategori baik. Jadi, dengan penerapan model pembelajaran inquiri terbimbing dapat meningkatkan motivasi belajar siswa dan kemampuan berpikir kritis siswa.
\end{abstract}

A B S T R A K

This study aims to examine the implementation of guided inquiry learning models to improve learning motivation and critical thinking skills. This type of research is Classroom Action Research (PTK) which is conducted in two cycles. The subjects of this study were students of class XI. which amounted to 30 people consisting of 5 female students and 25 male students. Data were collected by means of a questionnaire and essay-type critical thinking skills test. The data collected was then analyzed descriptively. The results showed 1) the application of the guided inquiry learning model was able to increase student learning motivation. The average score of student learning motivation is in the high category with an average score of 103.73 in the first cycle and 109.27 in the second cycle with the high category. 2) The application of guided inquiry learning models can improve students' critical thinking skills. The average value of students' critical thinking skills is in the good category with classical completeness of $87.1 \%$ in the first cycle and classical completeness of $90.6 \%$ in the second cycle with a good category. So, by applying the guided inquiry learning model, it can increase students 'learning motivation and students' critical thinking skills

\section{Pendahuluan}

Pekembangan zaman saat ini menuntut terbentuknya manusia yang mempunyai kemampuan berpikir kritis. Berpikir kritis merupakan suatu proses yang memungkinkan siswa membangun pengetahuan melalui pemecahan masalah dan kolaborasi (Putri et al., 2019). Kemampuan berpikir kritis ini dapat dilatihkan di sekolah manapun melalui suatu proses belajar yang sifatnya inovatif, kreatif dan menyenangkan (Farida et al., 2017). Kemampuan berpikir kritis setiap individu berbeda-beda, tergantung 
pada latihan yang se- ring dilakukan untuk mengembangkan berpikir kritis (Fakhriyah, 2014). Berpikir kritis dalam pembelajaran bertujuan untuk mengarahkan siswa untuk memiliki cara berpikir yang terstruktur dan cerdas dalam mengorganisasikan antar konsep untuk memecahkan masalah (Umam, 2018). Kemampuan berpikir kritis akan membuat mereka tangguh dalam menghadapi berbagai persoalan, mampu menyelesaikannya dengan tepat, dan mampu mengaplikasikan materi pengetahuan yang diperoleh di bangku sekolah dengan berbagai situasi berbeda dalam kehidupan nyata sehari-hari (Wati \& Anggraini, 2019). Pentingnya kemampuan berpikir kritis, menuntut siswa untuk belajar menemukan pengetahuanya sendiri. Proses belajar yang dapat mengembangkan kemampuan berpikir kritis tentunya diperoleh dari proses pembelajaran yang disusun dengan baik dan inovatif.

Namun hal tersebut belum sesuai dengan kenyataan yang dialami oleh siswa di SMK Negeri 1 Mas Ubud. Upaya pemerintah menyempurnakan kurikulum belum diiringi dengan peningkatan prestasi belajar siswa sesuai dengan harapan. Upaya pemerintah haruslah sejalan dengan apa yang dilaksanakan oleh sekolah, terutama guru-guru yang memegang peranan penting dan lebih bertanggung jawab terhadap hasil yang diperoleh peserta didik. Fakta terkait belum sesuainya harapan pemerintah tersebut terlihat di kelas XI.TKJ SMK Negeri 1 Mas Ubud yang merupakan kelas pavorit di sekolah tersebut. Kelas XI.TKJ memiliki kemampuan dibidang kognitif lebih tinggi dibandingkan kelas lainnya seharusnya memberikan pengaruh yang linear terhadap prestasi belajar yang di dapatkan. Hasil obervasi yang dilaksanakan terungkap bahwa rata-rata nilai ulangan siswa pada mata pelajaran fisika kelas XI.TKJ SMK Negeri 1 Mas Ubud pada semester ganjil tahun 2018/2019 belum mencapai ketuntasan klasikal minimal yang ditetapkan sekolah yaitu $85 \%$. Perolehan ketuntasan klasikal rata-rata prestasi belajar siswa di kelas XI.TKJ adalah 3,12\% dengan Kriteria Ketuntasan Minimal (KKM) yang digunakan adalah 67. Siswa lebih banyak memahami pelajaran dari buku catatan, sehingga belum secara optimal mengembangkan kemampuan berpikir kritis dan kreatif dalam pemecahan masalah (Suprapto, 2017). Rendahnya siswa mencapai KKM disebabkan oleh beberapa hal antara lain pembelajaran yang masih bersifat teacher centered, aktivitas siswa selama pembelajaran masih dikekang dan dikuasai oleh guru sehingga tidak memiliki kesempatan untuk mengembangkan potensi yang ada dalam dirinya, guru kurang memotivasi siswa di awal pembelajaran dan siswa cenderung berpikir bahwa tujuan belajar hanya untuk menjawab soal saat ulangan. Alasan-alasan ini tentunya akan sangat berpengaruh terhadap motivasi siswa dalam mengikuti pembelajaran. Proses pembelajaran akan menjadi membosankan sehingga akan mempengaruhi motivasi dan hasil belajar siswa (Adnyani et al., 2020). Pelajaran yang komunikatif dan menarik merupakan salah satu cara untuk menarik minat dan memotivasi siswa untuk mencerna pelajaran yang di sampaikan (Gustina et al., 2016). Motivasi belajar yang tinggi yang pada akhirnya dapat meningkatkan hasil belajarnya (Faradilla, 2017; Suprapto, 2017). Seperti yag sudah dijabarkan bahwa motivasi siswa dalam pembelajaran akan terbentuk jika proses pembelajaran dilakukan dengan model pembelajaran Inovatif. Salah satu model pembelajaran Inovatif yang bisa digunakan adalah model pembelajaran Inkuiri terbimbing.

Model pembelajaran inkuiri terbimbing merupakan model pembelajaran yang menempatkan peserta didik sebagai subjek pembelajaran yang berarti setiap peserta didik didorong terlibat aktif dalam kegiatan pembelajaran (Harjilah et al., 2019). Model inkuiri merupakan model pembelajaran yang melatih siswa untuk belajar menemukan masalah, mengumpulkan, mengorganisasi, dan memecahkan masalah ( Kristianingsih \& Khanafiyah, 2010). Model inkuiri memberikan kesempatan siswa untuk mengeksplor seluruh kemampuan siswa dalam mengungkap atau menjawab masalah dan membahas topik yang diangkat (Mohammad et al., 2017). inkuiri dapat memberikan ruang kepada siswa untuk belajar sesuai dengan gaya belajar siswa (Nilasari \& Adrian, 2009). Model inkuiri menekankan kepada aktivitas siswa secara maksimal untuk mencari dan menemukan (Sutarti \& Wibawa, 2018). Metode inkuiri harus memenuhi empat kriteria ialah kejelasan, kesesuaian, ketepatan dan kerumitannya. Siswa benar-benar ditempatkan sebagai subjek yang belajar. Peranan guru dalam pembelajaran dengan metode inkuiri adalah sebagai pembimbing dan fasilitator (Muliani \& Wibawa, 2019). Jabaran tentang model Inkuiri tentunya menjadikan alasan mengapa penelitian ini dilakukan. Penelitian ini bertujuan untuk mengkaji implementasi model inkuiri terbimbing untuk meningkatkan motivasi dan berpikir kritis siswa. Dengan adanya model inkuiri ini tentunya akan memberikan dapak yang positif terhadap proses pembelajaran karena pembelajaran inkuiri terbimbing memberikan kesempatan siswa belajar dengan aktif melalui penemuan. Tentunya hal ini akan memberikan dampak terhadap motivasi belajar dan kemampuan bepikir kritis siswa.

\section{Metode}

Jenis penelitian yang dilakukan tergolong penelitian tindakan kelas (classroom action research) yang secara umum bertujuan untuk meningkatkan motivasi belajar dan kemampuan berpikir kritis siswa 
kelas XI.TKJ SMK Negeri 1 Mas Ubud tahun pelajaran 2018/2019. Objek penelitian dalam penelitian ini adalah (a) model pembelajaran inkiri terbimbing dalam pembelajaran Fisika; (b) motivasi belajar siswa; (c) kemampuan berpikir kritis siswa terhadap implementasi model pembelajaran inkuiri terbimbing dalam pembelajaran Fisika. Penelitian Tindakan Kelas (PTK) dilakukan dalam 2 siklus yang terdiri dari empat tahapan yang diadaptasi dari Riel (Pardede, 2011), yaitu 1) perencanaan, 2) tindakan, 3) observasi/evaluasi, dan 4) refleksi. Data penelitian ini meliputi: 1) kemampuan berpikir kritis, dan 2) motivasi belajar siswa terhadap model pembelajaran inkuri terbimbing. Teknik pengumpulan data kemampuan berpikir kritis siswa berupa tes tipe esai yang di validasi isi oleh 2 orang guru. Tes diberikan pada akhir siklus dengan berpatokan pada rubrik penilaian yang telah disusun, yaitu 1) mengidentifikasi permasalahan yang terkandung dalam tes essay dan menemukan apa yang diperlukan soal, 2) menuliskan dasar pemikiran untuk menjawab soal sesuai dengan konsep yang benar, 3) penggunaan dan pemilihan prosedural penyelesaian yang tepat dalam menyelesaikan soal, 4) memeriksa, mengoreksi, dan menuliskan penyelesaian yang benar untuk permasalahan. Penelitian ini dikatakan berhasil jika rata-rata kemampuan berpikir kritis siswa secara klasikal minimal berada pada kategori baik dengan ketuntasan klasikal minimal 85\%. Teknik pengumpulan data motivasi belajar siswa berupa angket yang diberikan pada setiap akhir siklus. Penelitian tindakan kelas ini dikatakan berhasil, bila rata-rata skor motivasi belajar siswa minimal berada pada kategori tinggi.

\section{Hasil dan Pembahasan}

\section{Hasil Siklus I}

Proses pembelajaran pada siklus I berlangsung dalam 4 kali pertemuan, yang terdiri dari 3 kali pertemuan untuk kegiatan belajar mengajar dan 1 kali pertemuan untuk tes akhir siklus. Materi yang dibahas pada siklus I adalah suhu dan temperatur, pemuaian dan perubahan wujud zat. Hasil analisis data motivasi belajar fisika siswa, diketahui rata-rata skor motivasi belajar fisika siswa kelas XI.TKJ sebesar 103,73 dengan kategori tinggi. deskripsi skor motivasi belaajr fisika siswa disajikan pada Tabel 1.

Tabel 1. Deskripsi Skor Motivasi Belajar Fisika Siswa pada Akhir Siklus I

\begin{tabular}{cc}
\hline Deskripsi & $\begin{array}{c}\text { Motivasi Belajar Fisika Siswa } \\
\text { Akhir Siklus I }\end{array}$ \\
\hline Rata-Rata & 103,73 \\
Standar Deviasi & 9,36 \\
Nilai Terendah & 88 \\
Nilai Tertingi & 122 \\
\hline
\end{tabular}

Hasil analisis data yang telah dilakukan, sebaran nilai kemampuan metakognitif siswa disajikan pada Tabel 2.

Tabel 2. Deskripsi Hasil Tes Kemampuan Berpikir Kritis Siswa pada Siklus I

\begin{tabular}{lc}
\hline Deskripsi & Kemampuan Berpikir Kritis \\
Akhir Siklus I
\end{tabular}

Hasil tes kemampuan berpikir kritis siswa pada siklus I berada pada kategori baik dengan ratarata nilai 79,1. Ketuntasan klasikal pada siklus I dalam penelitian ini sebesar 87,1\%. Hasil penelitian siklus I menunjukkan semua kriteria keberhasilan penelitian ini telah tercapai yaitu motivasi belajar fisika siswa sudah berada pada kategori tinggi, serta hasil tes kemampuan berpikir kritis siswa berada pada kategori baik dengan ketuntasan klasikal sebesar $87,1 \%$ melebihi standar minimal ketuntasan klasikal yang ditetapkan sekolah sebesar $85 \%$. 


\section{Siklus II}

Kegiatan yang dilakukan dalam proses pembelajaran mengacu pada hasil refleksi dari kegiatan yang dilakukan pada siklus I. Proses pembelajaran pada siklus II dikemas menjadi 3 kali pertemuan. Materi yang dibahas pada siklus II adalah perpindahan kalor dan pertukaran kalor (Azas Black). Hasil penelitian siklus II meliputi motivasi belajar fisika dan kemampuan berpikir kritis siswa terhadap implementasi model pembelajaran inkuiri terbimbing. Hasil analisis data motivasi belajar fisika siswa, motivasi belajar fisika siswa kelas XI.TKJ mengalami peningkatan. Deskripsi skor motivasi belajar fisika siswa disajikan pada Tabel 3.

Tabel 3. Deskripsi Skor Motivasi Belajar Fisika Siswa pada Akhir Siklus I dan II

\begin{tabular}{ccc}
\hline \multirow{2}{*}{ Deskripsi } & \multicolumn{2}{c}{ Motivasi Belajar Fisika Siswa } \\
\cline { 2 - 3 } & Akhir Siklus I & Akhir Siklus II \\
\hline Rata-Rata & 103,73 & 109,27 \\
Standar Deviasi & 9,36 & 8,646 \\
Nilai Terendah & 88 & 91 \\
Nilai Tertingi & 122 & 127 \\
\hline
\end{tabular}

Rata-rata skor motivasi belajar fisika siswa pada akhir siklus I sebesar 103,73 dengan kategori tinggi dan pada akhir siklus II sebesar 109,27 dengan kategori tinggi, dengan demikian terjadi peningkatan motivasi belajar pada siklus II dilihat dari rata-rata nilai motivasi belajar meskipun kategori pada siklus II sama yaitu berada pada kategori tinggi. Secara klasikal rata-rata nilai kemampuan berpikir kritis siswa pada siklus I berada pada kategori sangat baik dengan rata-rata nilai 90,1. Ketuntasan klasikal yang tercapai pada siklus II adalah 90,6\%. Deskripsi hasil tes kemampuan berpikir kritis siswa siklus I pada Tabel 4.

Tabel 4. Deskripsi Hasil Tes Kemampuan Berpikir Kritis Siswa pada Siklus I dan Siklus II

\begin{tabular}{|c|c|c|}
\hline \multirow{2}{*}{ Deskripsi } & \multicolumn{2}{|c|}{ Kemampuan Berpikir Kritis } \\
\hline & Akhir Siklus I & Akhir Siklus II \\
\hline Rata-Rata & 79,1 & 90,1 \\
\hline Standar Deviasi & 8,2 & 7,9 \\
\hline Nilai Terendah & 57 & 65 \\
\hline Nilai Tertinggi & 93 & 98 \\
\hline Frekuensi > KKM & 27 & 29 \\
\hline Frekuensi < KKM & 3 & 1 \\
\hline
\end{tabular}

Berdasarkan analisis terhadap proses penerapan model pembelajaran inkuri terbimbing pada siklus I dan siklus II, terungkap pembelajaran pada siklus I terlihat belum optimal. Hal ini ditunjukkan dari adanya beberapa kemampuan dan prilaku siswa yang belum sesuai dengan harapan. Siswa belum berani mengemukakan pendapatnya dan tampak canggung ketika menganggapi pertanyaan ataupun pada saat bertanya. Kegiatan diskusi dalam setiap kelompok juga terlihat belum optimal. Hasil analisis siklus I masih dapat dimaklumi karena siswa berlum terbiasa dengan model pembelajaran yang diterapkan yaitu model pembelajaran inkuiri terbimbing. Hasil dari analisis data motivasi siswa pada siklus I menunjukkan ratarata skor motivasi belajar siswa di akhir siklus I sebesar 103,73 dengan kategori tinggi. Hasil ini menjelaskan model pembelajaran inkuiri terbimbing pada siklus I mampu meningkatkan motivasi belajar siswa baik dari aspek intrinsik, ekstrinsik, arah tujuan, ketepatan diri, kepercayaan diri, dan mengurangi kecemasan pada penilaian. Hasil analisis data menunjukkan kemampuan berpikir kritis pada siklus I sudah mencapai kategori baik dengan rata-rata nilai sebesar 79,1. Hal ini menjelaskan model pembelajaran inkuri terbimbing pada siklus I mampu meningkatkan kemampuan berpikir kritis siswa baik dari aspek kemampuan mengidentifikasi masalah, kemampuan dalam menuliskan dasar pemikiran yang akan digunakan, kemampuan dalam menggunakan prosedur penyelesaian yang tepat, dan kemampuan dalam memeriksa/mengoreksi penyelesaian yang benar dalam permasalahan yang diberikan. Hasil yang didapatkan pada siklus I senada dengan hasil penelitian yang dilakukan oleh Syarifudin dan Sugiarto (2012) mengungkapkan bahwa model pembelajaran inkuri terbimbing mampu meningkatkan kemampuan berpikir kritis siswa yang dilihat dari persentase kemampuan berpikir kritis siswa yang meningkat 56,7\% dari siswa dengan kategori rendah menjadi kategori tinggi.

Pada pelaksanaan siklus II, kegiatan pembelajaran telah lebih dioptimalkan sesuai dengan hasil refleksi siklus I. Secara ringkas, keseluruhan hasil refleksi pada siklus I tersebut, yaitu 1) mengoptimalkan 
kerjasama kelompok, 2) meminimalkan dominasi beberapa individu atau kelompok, 3) meningkatkan motivasi belajar, 4) meminimalkan kadar pemberian tuntunan, 5) meningkatkan kepercayaan diri siswa dalam melakukan presentasi, 6) membuat LKS yang lebih rinci dan mudah dipahami oleh siswa, 7) merancang RPP agar sesuai dengan alokasi waktu yang tersedia. Semua hasil refleksi tersebut nantinya akan bermuara pada pelaksanaan pembelajaran pada siklus II yang diharapkan lebih baik dari siklus I. Upaya peningkatan yang dilakukan pada siklus II menunjukkan hasil yang positif. Berdasarkan hasil penelitian pada siklus II, terungkap bahwa terjadi peningkatan motivasi dan nilai kemampuan berpikir kritis siswa dari siklus I. Hasil penelitian menunjukkan bahwa tingkat motivasi belajar fisika siswa tergolong tinggi. Rata-rata nilai kemampuan berpikir kritis siswa pada siklus II berada pada kategori sangat tinggi dengan rata-rata nilai sebesar 90,1. Ketuntasan klasikal pada siklus II sebesar 90,6\% yang berada diatas ketuntasan minimal sebesar $85 \%$. Secara klasikal terjadi kenaikan dari siklus I sampai siklus II, yaitu dari $87,1 \%$ menjadi $90,6 \%$. Hal ini berarti, penelitian yang telah dilakukan berhasil memenuhi kriteria keberhasilan dalam meningkatkan motivasi dan kemampuan berpikir kritis siswa kelas XI.TKJ SMK Negeri 1 Mas Ubud tahun pelajaran 2018/2019.

Pembelajaran yang berpedoman dengan paham konstruktivis selalu memberdayakan pengetahuan awal siswa dalam proses pembelajaran. Pemberdayaan pengetahuan awal ini diintegrasikan dalam pembelajaran dengan penerapan model pembelajaran inkuiri terbimbing. Sebagai contoh, dalam pelaksanaan kegiatan pendahuluan, pengetahuan awal siswa selalu digali terkait dengan apa yang mereka ketahui tentang konsep yang dipelajari. Hasil pemberdayaan pengetahuan awal ini kemudian dijadikan pijakan dalam mewujudkan pembelajaran yang efektif. Pemilihan model yang sebaiknya diterapkan adalah model pembelajaran yang melibatkan peserta didik secara aktif serta mampu mengajak siswa untuk membangun pengetahuannya sendiri karena pengetahuan yang dibangun sendiri oleh siswa cenderung bersifat menetap atau tertanam pada memori otak jangka panjangnya (Suryantari et al., 2019). Model pembelajaran inkuri terbimbing yang bersifat student centered serta pemberdayaan pengetahuan awal siswa dapat meningkatkan aktivitas siswa. Hal ini terjadi karena konsep yang dibelajarkan telah terkait dengan fenomena yang sesuai dengan pengetahuan awal siswa. Hal ini mampu menambah kebermaknaan belajar dan meningkatnya motivasi belajar siswa. Proses pembelajaran akan menjadi membosankan sehingga akan mempengaruhi motivasi dan hasil belajar siswa (Adnyani et al., 2020). Pelajaran yang komunikatif dan menarik merupakan salah satu cara untuk menarik minat dan memotivasi siswa untuk mencerna pelajaran yang di sampaikan (Gustina et al., 2016). Motivasi belajar yang tinggi yang pada akhirnya dapat meningkatkan hasil belajarnya (Faradilla, 2017; Suprapto, 2017).

Menggunakan pembelajaran inkuiri terbimbing harus menggunakan konteks yang benar-benar telah dikenal baik oleh siswa serta merupakan aplikasi dalam kehidupan nyata yang dijadikan sebagai titik tolak proses pembelajaran sehingga dapat memberikan kemudahan kepada siswa untuk memahami konsep materi matematika yang telah diajarkan (Febriawan, 2016). Model pembelajaran inkuiri terbimbing merupakan model pembelajaran yang menempatkan peserta didik sebagai subjek pembelajaran yang berarti setiap peserta didik didorong terlibat aktif dalam kegiatan pembelajaran (Harjilah et al., 2019). Model inkuiri merupakan model pembelajaran yang melatih siswa untuk belajar menemukan masalah, mengumpulkan, mengorganisasi, dan memecahkan masalah (Kristianingsih \& Khanafiyah, 2010). Model inkuiri memberikan kesempatan siswa untuk mengeksplor seluruh kemampuan siswa dalam mengungkap atau menjawab masalah dan membahas topik yang diangkat (Mohammad et al., 2017). inkuiri dapat memberikan ruang kepada siswa untuk belajar sesuai dengan gaya belajar siswa (Nilasari \& Adrian, 2009). Model inkuiri menekankan kepada aktivitas siswa secara maksimal untuk mencari dan menemukan (Sutarti \& Wibawa, 2018). Metode inkuiri harus memenuhi empat kriteria ialah kejelasan, kesesuaian, ketepatan dan kerumitannya. Siswa benar-benar ditempatkan sebagai subjek yang belajar. Peranan guru dalam pembelajaran dengan metode inkuiri adalah sebagai pembimbing dan fasilitator (Muliani \& Wibawa, 2019). Model pembelajaran seperti ini tentunya akan memebrikan dampak positif terhadap pengembangan kemampuan berfikir kritis siswa.

Berpikir kritis merupakan suatu proses yang memungkinkan siswa membangun pengetahuan melalui pemecahan masalah dan kolaborasi (Putri et al., 2019). Kemampuan berpikir kritis ini dapat dilatihkan di sekolah manapun melalui suatu proses belajar yang sifatnya inovatif, kreatif dan menyenangkan (Farida et al., 2017). Kemampuan berpikir kritis setiap individu berbeda-beda, tergantung pada latihan yang se- ring dilakukan untuk mengembangkan berpikir kritis (Fakhriyah, 2014). Berpikir kritis dalam pembelajaran bertujuan untuk mengarahkan siswa untuk memiliki cara berpikir yang terstruktur dan cerdas dalam mengorganisasikan antar konsep untuk memecahkan masalah (Umam, 2018). Kemampuan berpikir kritis akan membuat mereka tangguh dalam menghadapi berbagai persoalan, mampu menyelesaikannya dengan tepat, dan mampu mengaplikasikan materi pengetahuan yang diperoleh di bangku sekolah dengan berbagai situasi berbeda dalam kehidupan nyata sehari-hari (Wati \& Anggraini, 2019). Pentingnya kemampuan berpikir kritis, menuntut siswa untuk belajar menemukan 
pengetahuanya sendiri. Proses belajar yang dapat mengembangkan kemampuan berpikir kritis tentunya diperoleh dari proses pembelajaran yang disusun dengan baik dan inovatif.

Secara keseluruhan, hasil analisis baik secara teoritis maupun operasional dari implementasi model pembelajaran inkuri terbimbing, ternyata mendukung keberhasilan penelitian tindakan kelas ini. Penelitian ini tergolong berhasil meningkatkan hasil belajar fisika ditinjau dari aspek kemampuan berpikir kritis siswa di kelas XI.TKJ SMK Negeri 1 Mas Ubud tahun pelajaran 2018/2019 karena mampu mencapai indikator peningkatan dan memenuhi kriteria keberhasilan yaitu hasil kemampuan berpikir kritis yang berkategori baik.

\section{Simpulan dan Saran}

Berdasarkan hasil penelitian maka dapat diambil simpulan sebagai beriku. Model Inkuiri adanya model inkuiri ini tentunya akan memberikan dapak yang positif terhadap proses pembelajaran karena pembelajaran inkuiri terbimbing memberikan kesempatan siswa belajar dengan aktif melalui penemuan. Tentunya hal ini akan memberikan dampak terhadap motivasi belajar dan kemampuan bepikir kritis siswa

\section{Daftar Rujukan}

Adnyani, N. K. M., Pudjawan, K., \& Japa, I. G. N. (2020). Motivasi dan Hasil Belajar IPA dalam Pembelajaran Scramble Berbantuan Kartu Pertanyaan. Jurnal Ilmiah Sekolah Dasar, 4(2), 270. https://doi.org/10.23887/jisd.v4i2.25622.

D.D. Kristianingsih, S., \& Khanafiyah, S. (2010). Peningkatan Hasil Belajar Siswa Melalui Model Pembelajaran Inkuiri Dengan Metode Pictorial Riddle Pada Pokok Bahasan Alat- Alat Optik Di Smp. Jurnal Pendidikan Fisika Indonesia, 6(1), 10-13. https://doi.org/10.15294/jpfi.v6i1.1095.

Fakhriyah. (2014). Penerapan Problem Based Learning dalam Upaya Mengembangkan Kemampuan Berpikir Kritis Mahasiswa. Jurnal Pendidikan IPA Indonesia, 3(1), 95-101. https://journal.unnes.ac.id/nju/index.php/jpii/article/view/2906.

Faradilla. (2017). Pengaruh Fasilitas Belajar, Lingkungan Keluarga, Dan Motivasi Belajar Terhadap Hasil Belajar Geografi Siswa IPS SMA Negeri Se-Kabupaten Jombang. Swara Bhumi, 5(1), 93-98.

Farida, U., Agustini, F., \& Wakhyudin, H. (2017). Efektivitas Model Pembelajaran Scramble Berbasis Kontekstual Terhadap Kemampuan Berpikir Kritis Ips Siswa Kelas Iii Sd Negeri Kebondalem 01 Batang. Jurnal Ilmiah Sekolah Dasar, 1(3), 192-199.

Febriawan, Y. (2016). Pembelajaran Inkuiri Terbimbing pada Siswa Kelas V SDN Balonggemek 1 Jombang. Jurnal Pendidikan: Teori, Penelitian, Dan Pengembangan, 1(9). http://journal.um.ac.id/index.php/jptpp/article/view/6742/2935.

Gustina, Abu, S. H. N., \& Hamsyah, E. F. (2016). Pengaruh Penggunaan Media Pembelajaran Berbasis Macromedia Flash 8 Terhadap Motivasi dan Hasil Belajar Kognitif Peserta didik Kelas VII SMPN 18 Makassar Studi pada Materi Pokok Asam, Basa dan Garam. Jurnal Ilmiah Kimia Dan Pendidikan Kimia, 17(2), 12-18.

Harjilah, N., Medriati, R., \& Hamdani, D. (2019). Pengaruh Model Inkuiri Terbimbing Terhadap Keterampilan Berpikir Kritis Pada Mata Pelajaran Fisika. Jurnal Kumparan Fisika, 2(2), 79-84. https://doi.org/10.33369/jkf.2.2.79-84.

Mohammad, F. H., Suwignyo, H., \& Mudiono, A. (2017). Penerapan Model Inkuiri untuk Meningkatkan Aktivitas dan Hasil Belajar IPA pada Siswa KELAS V. Jurnal Pendidikan - Teori, Penelitian, Dan Pengembangan, 1, 20-29. https://doi.org/http://dx.doi.org/10.17977/jptpp.v2i12.10315.

Muliani, N. K. D., \& Wibawa, I. M. C. (2019). Pengaruh Model Pembelajaran Inkuiri Terbimbing Berbantuan Video Terhadap Hasil Belajar IPA. Jurnal Ilmiah Sekolah Dasar, 3(1), 107-114. https://doi.org/10.31539/spej.v2i1.333.

Nilasari, E., \& Adrian, Y. (2009). Implementasi Model Pembelajaran Inquiri Terbimbing Untuk Meningkatkan Hasil Belajar Siswa Kelas IV SDN Mulyoagung 3 Dau Malang Yudha Adrian. 74-80.

Putri, O. D., Nevrita, N., \& Hindrasti, N. E. K. (2019). Pengembangan Instrumen Penilaian Keterampilan Berpikir Kritis Siswa Sma Pada Materi Sistem Pencernaan. BIOEDUKASI (Jurnal Pendidikan Biologi), 10(1), 14. https://doi.org/10.24127/bioedukasi.v10i1.2004. 
Suprapto, E. (2017). Pengaruh Model Pembelajaran Kontekstual, Pembelajaran Langsung Dan Motivasi Berprestasi Terhadap Hasil Belajar Kognitif. Innovation of Vocational Technology Education, 11(1), 23-40. https://doi.org/10.17509/invotec.v11i1.4836.

Suryantari, N. M. A., Pudjawan, K., \& Wibawa, I. M. C. (2019). Pengaruh Model Pembelajaran Inkuiri Terbimbing Berbantuan Media Benda Konkret terhadap Sikap Ilmiah dan Hasil Belajar IPA. Jurnal Pendidikan, 3(3), 316-326. https://doi.org/http://dx.doi.org/10.23887/ijee.v3i3.19445.

Sutarti, N. P. S. E., \& Wibawa, I. M. C. (2018). Penerapan Model Pembelajaran Inkuiri Berbantuan Media Konkret Untuk Meningkatkan Hasil Belajar Muatan Pelajaran Matematika. Journal of Education Action Research, 2(4), 295. https://doi.org/10.23887/jear.v2i4.16319.

Umam, K. (2018). Peningkatan Kemampuan Berpikir Kritis Matematis Siswa Melalui Pembelajaran Reciprocal Teaching. Jurnal Pendidikan Matematika Indonesia, 3(2), 57-61. https://doi.org/https://dx.doi.org/10.26737/jpmi.v3i2.807.

Wati, M., \& Anggraini, W. (2019). Strategi Pembelajaran Kooperatif Tipe Jigsaw: Pengaruhnya Terhadap Kemampuan Berpikir Kritis Siswa. Indonesian Journal of Science and Mathematics Education, 2(1), 98-106. https://doi.org/10.24042/ijsme.v2i1.3976. 